\title{
Bacterial numbers and activity, microalgal biomass and productivity, and meiofaunal distribution in sediments naturally contaminated with biogenic bromophenols ${ }^{* * *}$
}

\author{
Charles C. Steward, J. Pinckney, Yvette Piceno, Charles R. Lovell \\ Department of Biological Sciences and Belle W. Baruch Institute for Marine Biology and Coastal Research, University of \\ South Carolina, Columbia, South Carolina 29208, USA
}

\begin{abstract}
Sediment cores were collected inside and outside of a bed of a bromophenol-producing marine polychaete, Notomastus lobatus, and examined for impact of the bromophenols on sediment microflora and meiofauna around $N$. lobatus burrows. No significant differences were found between microbial parameters measured inside and outside of the $N$ lobatus bed. Integrated $6 \mathrm{~cm}$ cores taken adjacent to $N$. lobatus burrows contained $1.2 \times 10^{9}$ bacteria $\mathrm{ml}^{-1}$. Cell numbers were similar at control sites within the bed, but away from burrows, and not significantly different from cell numbers $\left(1.0 \times 10^{9}\right.$

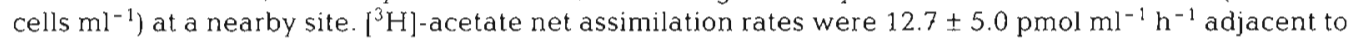
burrows and $11.9 \pm 1.4 \mathrm{pmol} \mathrm{ml}^{-1} \mathrm{~h}^{-1}$ in non-burrow control cores. Microalgal biomass was $20.1 \pm 1.2$

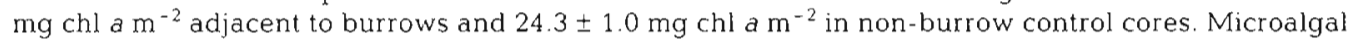
production was $4.17 \pm 0.31 \mathrm{mmol} \mathrm{O}_{2} \mathrm{~m}^{-2} \mathrm{~h}^{-1}$ near burrows and $5.84 \pm 0.97 \mathrm{mmol} \mathrm{O} \mathrm{m}^{-2} \mathrm{~h}^{-1}$ in nonburrow controls. Distribution of bacteria, microalgae, and meiofauna showed no consistent effects of proximity to the worm burrows. These data indicate that the concentrations of bromophenols found inside of the $N$. lobatus worm bed are not inhibitory to sediment microflora and that the microbial populations found there are adapted to exposure to these toxic compounds.
\end{abstract}

\section{INTRODUCTION}

Toxic halometabolites are produced by a variety of marine organisms, including algae (Pedersen et al. 1974, Fenical 1975, Hewson \& Hager 1980, Faulkner 1984), jellyfish (White \& Hager 1977), sponges (Schmitz \& Gopichand 1978), mollusks (Jannun et al. 1981), and polychaete and hemichordate worms (Ashworth \& Cormier 1967, Higa \& Scheuer 1975a, b, Sheikh \& Djerassi 1975, Woodin et al. 1987, Goerke \& Weber 1991, Woodin 1991). A variety of worm species produce one or more brominated compounds, including bromophenols, bromopyrroles, and bromobenzyl-

- Contribution No. 967 from the Belle W. Baruch Institute for Marine Biology and Coastal Research

- A preliminary account of this work was presented at the 92nd General Meeting of the American Society for Microbiology, New Orleans, LA, USA, in 1992 (Steward et al. 1992) alcohols (Woodin et al. 1987, Woodin 1991). The bromometabolites appear to be released in or with mucus from the animals and are distributed into surrounding sediments by the burrowing, burrow irrigation, and defecation activities of the worms (Woodin \& Marinelli 1991). The resulting contamination of sediments with toxic brominated compounds is an important feature of areas inhabited by these worms. Worm beds are often very stable communities (Beukema \& de Vlas 1979, Beukema 1982), retaining roughly the same species compositions and, presumably, levels of bromometabolite contamination for many years.

Several infaunal polychaetes and hemichordates common in southeastern U.S. estuaries produce bromometabolites (Woodin et al. 1987). These organisms contaminate the areas they inhabit, with bromometabolites reaching concentrations in surrounding sediments and water ranging from nanomolar to several micromolar (Lincoln, Fielman, Lovell, \& Woodin un- 
publ.). Among the bromometabolite producing polychaetes is the capitellid Notomastus lobatus, an abundant worm in some of the intertidal sandflats of the North Inlet (Georgetown, South Carolina, USA) salt marsh. $N$. lobatus is a head-down deposit feeder which produces a distinctive spiral burrow (Powell 1977) with a crescent-shaped opening. Burrows are contaminated with biogenic bromophenols, specifically 4-bromophenol, 2,4-dibromophenol, and 2,4,6-tribromophenol (Lincoln, Fielman, Lovell, \& Woodin unpubl.). Contamination of surrounding sediments also occurs, but at lower levels. The bromophenols are present at very high levels in $N$. lobatus tissues and are produced through the action of a specific chloroperoxidase (Chen et al. 1991). The bromophenols found in the $N$. lobatus tissues, burrows, and in the surrounding worm bed sediments are clearly produced by this animal.

The purpose of bromophenol production by marine worms is currently unknown. Worm bromometabolites have been thought to serve as antifouling agents on the surfaces of the animals and within their burrows (Ashworth \& Cormier 1967, Sheikh \& Djerassi 1975, King 1986, Goerke \& Weber 1991, Jensen et al. 1992). It is clear however that significant inhibition of sediment microflora around the worm burrows could restrict potential sources of carbon and nitrogen for the worms (Newell 1965, Cammen 1980, Lopez \& Levinton 1987, Dobbs \& Guckert 1988, Pinckney \& Zingmark 1991), alter sediment texture by reducing production of diatom exopolymers (Holland et al. 1974), and substantially alter sediment biogeochemical processes. These impacts would be detrimental to the bromometabolite-producing worm species. Worm bromometabolites may instead function as antipredator compounds (Woodin et al. 1987. Woodin \& Marinelli 1991) or as negative cues in the recruitment of planktonic larvae of other benthic invertebrates (Woodin 1991), with relatively little impact on benthic microflora and meiofauna.

In this study we examined the effects of the 4-bromophenol, the principal brominated product of Notomastus lobatus, on the microflora and meiofauna in the sediments surrounding its burrows. Bacterial numbers and activity, microalgal biomass and productivity, and meiofaunal distribution in close proximity to $N$. lobatus burrows were compared to those in areas outside the worm bed in order to evaluate possible microbial and meiofaunal inhibition by worm bromometabolites.

\section{MATERIALS AND METHODS}

Sample sites. The North Inlet estuary $\left(33^{\circ} 20^{\prime} \mathrm{N}, 79^{\circ}\right.$ $10^{\prime} \mathrm{W}$ ) is a relatively small (3200 ha), bar-built Spartina

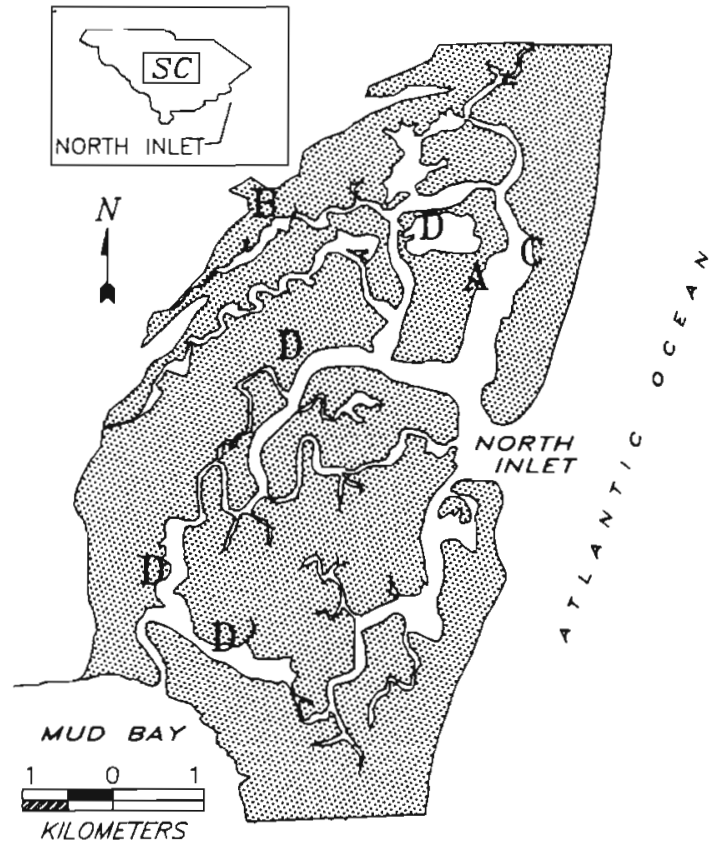

Fig. 1. North Inlet salt marsh estuary, Georgetown, South Carolina, USA. Sampling sites are indicated by capital letters

marsh system located near Georgetown, South Carolina, USA (Fig. 1). This euhaline estuary has semidiurnal tides with a mean range of $1.4 \mathrm{~m}$ (Dame et al. 1986). The dominant macrophyte is the saltmarsh cordgrass Spartina alterniflora, and the system contains numerous small creeks, intertidal sandflats, and oyster reefs. Sediments near the mouth of the estuary are generally composed of fine, well-sorted quartz sands with small amounts $(<10 \%$ by weight) of silts and clays. Further from the estuary mouth, sediments are composed of very fine sands mixed with large amounts 1>30\% by weight) of silts and clays (Pinckney \& Zingmark 1993).

The capitellid polychaete Notomastus lobatus occupies the lower intertidal and shallow subtidal zones of sandflats ( $3.1 \%$ silt \& clay at the site used in this study) and forms well-defined 'beds' with estimated densities as high as 20 ind. $\mathrm{m}^{-2}$. N. lobatus burrows are easily recognized in the field by their crescent shaped openings. After sampling in proximity to a burrow, the polychaete was exhumed and its identity confirmed. No other polychaetes at any of our sites resembled $N$. lobatus. Although 4-bromophenol, 2,4-dibromophenol, and 2,4,6-tribromophenol are produced by $N$. lobatus, 4 -bromophenol constitutes greater than $99 \%$ of the total bromophenol in the animal's tissues (Lincoln, Fielman, Lovell \& Woodin unpubl.), and over $86 \%$ of the total bromophenol contamination in worm bed sediments. 
Sampling and sample analysis. Sediment cores for bacterial cell counts and radiolabeling studies were taken using cut off $10 \mathrm{ml}(1.4 \mathrm{~cm}$ diameter, $6.1 \mathrm{~cm}$ length) plastic syringes with self-sealing $1 \mathrm{~mm}$ diameter injection ports at $1 \mathrm{~cm}$ vertical intervals. Sets of 6 sediment cores from close proximity $(2 \mathrm{~cm})$, and at distance from $(10 \mathrm{~cm})$ Notomastus lobatus burrows (Fig. 1, Site A) were collected for cell counts. Five sets of 7 sediment cores each were collected around N. lobatus burrows for radiolabeling studies and cell counts. Five sets of 7 cores each were also collected from an adjacent sandflat that did not have visible $N$. lobatus burrows (Fig. 1, Site A). In addition, 2 sets of 6 cores each were taken from muddy or sandy sediments at 2 different creekbank sites (Fig. 1, Sites B \& C) for cell counts and activity estimates in sediments without 4-bromophenol. Cores were injected with $2220 \mathrm{kBq}$ core $^{-1}$ (30 $\mu \mathrm{l}, 5 \mu \mathrm{l}$ per port) of ${ }^{3} \mathrm{H}$-acetate (specific activity $70.3 \mathrm{GBq} \mathrm{mmol}^{-1}$ ) following previously established methods (Steward \& Lovell 1992), and incubated for $4 \mathrm{~h}$ at in situ temperature. Previous experiments (Steward \& Lovell unpubl. data) showed acetate incorporation rates to be linear through $8 \mathrm{~h}$. Control cores were frozen on dry ice immediately after injection with radiolabel and formaldehyde. Multiple washes in $3.5 \%$ formaldehyde were used to remove unincorporated radiolabel, and the incorporated radiolabel was solubilized using strongly alkaline conditions (Steward \& Lovell 1992). Radiolabel incorporation was determined by liquid scintillation counting, and rates of ${ }^{3} \mathrm{H}$-acetate net assimilation were calculated. Previous uptake kinetic experiments (Steward \& Lovell 1992 unpubl. data) have shown that estimated sediment acetate concentrations are similar to published values for similar sediments, and are not highly variable in sediments within or between our study sites.

Separate experiments examined ${ }^{3} \mathrm{H}$-acetate net assimilation and ${ }^{14} \mathrm{C}$-acetate respiration rates in parallel. For assimilation and respiration rate measurements, cores were injected with ${ }^{3} \mathrm{H}$-acetate (see above) or with $880 \mathrm{kBq}$ core ${ }^{-1}\left(60 \mu \mathrm{l}, 10 \mu \mathrm{l}\right.$ per port) ${ }^{14} \mathrm{C}$-acetate (specific activity $2.1 \mathrm{GBq} \mathrm{mmol}^{-1}$ ), and incubated in the dark for $4 \mathrm{~h}$ at in situ temperature. Cores for ${ }^{3} \mathrm{H}$ acetate net assimilation rate measurements were processed as before. At time zero, 2 control cores for ${ }^{14} \mathrm{C}$ acetate respiration were extruded into $125 \mathrm{ml}$ flasks, connected to a gassing manifold and acidified. The liberated ${ }^{14} \mathrm{CO}_{2}$ was flushed into a series of 3 traps containing phenethylamine: methanol (1:2), using $\mathrm{N}_{2}$ as the carrier gas. The traps were subsampled and radioactivity determined. Following incubation, experimental cores were acidified and flushed using the same methods. For calculation of assimilation and respiration rates, radioactivity recovered from the controls was subtracted from that recovered from the experimental samples.

Sediment cores $(7.25 \mathrm{~cm}$ dia.) for benthic microalgal biomass and productivity measurements were collected in the worm bed $(n=5)$ (Fig. 1, Site A), from a nearby uncontaminated sandflat $(n=5)$ (Fig. 1, Site A), and from randomly chosen intertidal mudflats $(n=4)$ (Fig. 1. Site D). Worm bed cores were centered over Notomastus lobatus burrow openings. Core tubes were capped and immediately transported to the field laboratory for measurements. Chlorophyll a (chl a), used as a measure of microalgal biomass, was determined spectrophotometrically for the upper $2 \mathrm{~mm}$ depth interval by taking 5 subcores from each sediment core followed by cold extraction in $100 \%$ acetone for $48 \mathrm{~h}$ (Lorenzen 1967).

Gross microalgal primary productivity was measured as the rate of oxygen production using Clarkestyle oxygen microelectrodes, following established methods (Revsbech \& Jørgensen 1986, Pinckney \& Zingmark 1991). Because of microscale biomass patchiness (Pinckney \& Sandulli 1990), 5 production measurements were obtained at random locations within each core. The productivity measurement method consisted of illuminating the sediment sample with a fiber-optic light and measuring the initial slope of oxygen decrease at $50 \mu \mathrm{m}$ depth intervals immediately (within $1 \mathrm{~s}$ ) after darkening the sediment surface. Integrated production was calculated for each profile and all 5 profiles were averaged to estimate the mean productivity for each core. The light intensity (ca $1200 \mu$ Ein $\mathrm{m}^{-2} \mathrm{~s}^{-1}$ ) used for measurements exceeds saturation irradiance and promotes maximum productivity $\left(\mathrm{P}_{\max }\right)$. All production measurements were made during low tide because of the migratory rhythms associated with benthic diatoms (Pinckney \& Zingmark 1991, Pinckney, Piceno \& Lovell unpubl.).

The impact of bromophenol production by Notomastus lobatus on the spatial distributions of bacteria, microalgae and meiofauna near the burrows was examined by sampling with 24 -well $(16.5 \mathrm{~mm}$ dia., 17.0 $\mathrm{mm}$ deep) tissue culture plates having a $2 \mathrm{~mm}$ hole at the center of each well (Pinckney \& Sandulli 1990) (Fig. 2). Five plates were centered over worm burrows so that a marked well near the center of the plate corresponded to burrow location. Plates were pushed into the mud and excavated using a large mason's trowel. Plates for microalgal biomass were frozen in the field for later photopigment analysis. All 24 wells were used in determination of microalgal biomass. Plates for determination of bacterial cell numbers and meiofaunal numbers were transported on ice to Columbia, South Carolina, for subsampling. Subsamples (area $=0.238$ $\mathrm{cm}^{2}$ ) were taken from 8 randomly assigned wells and fixed in $3.5 \%$ formaldehyde for cell counts. Bacterial 


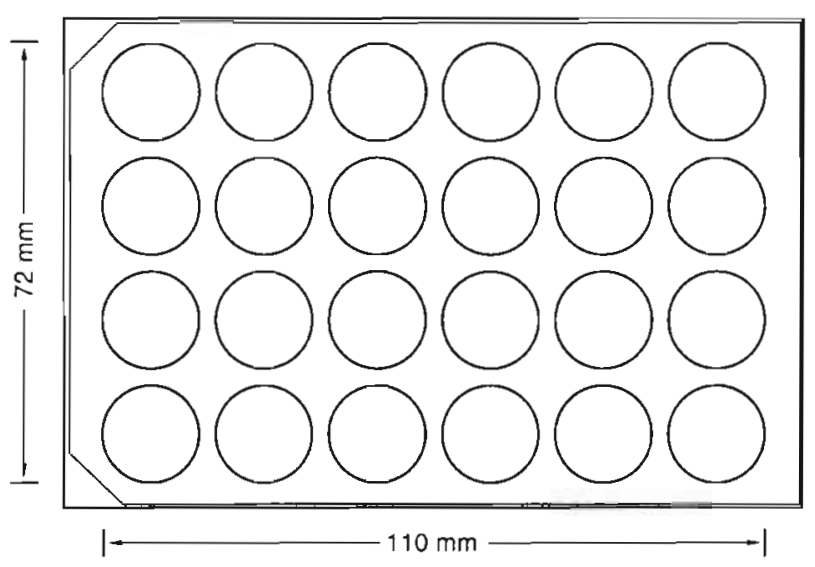

Fig. 2. Sampling plates used to determine bacterial numbers, microalgat biomass, and meiofaunal numbers at various discrete distances from Notomastus lobatus burrows

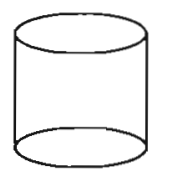

Diameter : $16.5 \mathrm{~mm}$ Height : $17.0 \mathrm{~mm}$ Volume : $3.6 \mathrm{ml}$

cell numbers were determined using the acridine orange direct count method of Hobbie et al. (1977) as modified for use in sediments (Yoon et al. 1990), Twelve subsamples (area $=0.238 \mathrm{~cm}^{2}$ ) for meiofaunal counts were taken from each plate and stained with Rose Bengal. The meiofauna were enumerated using a dissecting microscope. Foraminifera, nematodes, copepods, and polychaetes were counted separately.

Sediments collected from each location were extracted with methanol, $5 \mathrm{~g}$ of sodium sulfate was added to absorb excess water, and a known quantity of 2,6dichlorophenol was added as an internal standard. Sediments were shaken overnight; $150 \mathrm{rpm}$ at $4{ }^{\circ} \mathrm{C}$. Following initial extraction sediments were centrifuged at $200 \times g$ for $15 \mathrm{~m}$ in a clinical centrifuge and $3 \mathrm{ml}$ of the methanol extractant removed. Thirty milliliters of saturated sodium chloride solution, $\mathrm{pH} \mathrm{2,} \mathrm{was}$ added to the extract, followed by addition of $3 \mathrm{ml}$ of pentane. The mixture was vortexed for $15 \mathrm{~s}$, phases allowed to separate and the bromophenol-containing organic phase removed and saved. The pentane extraction step was repeated 4 more times resulting in a final extraction volume of $15 \mathrm{ml}$. The pentane fractions were concentrated and analyzed using a Varian Model 3300 gas chromatograph (Sunnyvale, CA, USA) equipped with a $15 \mathrm{~m} \times 0.53 \mathrm{~mm}$ ID fused silica capillary column coated with a $1.5 \mu \mathrm{m}$ film of cross linked SE-54 phase (DB-5, J \& W Scientific, Folsom, CA, USA), a ${ }^{63} \mathrm{Ni}$ electron capture detector and a Model 4400 integrator. The brominated compounds were resolved using a temperature program of 120 to $200^{\circ} \mathrm{C}$ at $10^{\circ} \mathrm{C} \mathrm{min}^{-1}, 30 \mathrm{ml} \mathrm{min}^{-1} \mathrm{~N}_{2}$ flow, and quantified using standard curves derived from known concentrations of authentic reagent-grade bromophenols obtained from Aldrich Chemical Co. (Milwaukee, WI, USA) and

Table 1. Concentrations of bromophenols in sediment samples taken from the different study sites (see Fig. 1). Compounds were quantified using gas chromatography. Integrated $=$ a $6 \mathrm{~cm}$ integrated core, and surface = sediment sample taken to a depth of

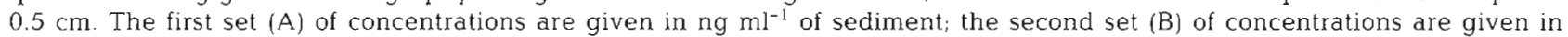
$n g g^{-1}$ (dry weight) of sediment; concentrations in parentheses are range of values for samples taken

\begin{tabular}{|c|c|c|c|c|}
\hline Location & (n) & 4-bromophenol & 2,4-dibromophenol & 2,4,6-tribromophenol \\
\hline \multicolumn{5}{|l|}{ (A) $\mathrm{ng} \mathrm{ml}^{-1}$} \\
\hline Burrows (Site A) & 5 & 146.1 & 11.5 & 2.3 \\
\hline Integrated & & $(75.3-306.5)$ & $(7.9-17.0)$ & $(2.0-2.5)$ \\
\hline Burrows (Site A) & 4 & 306.9 & 6.7 & 1.8 \\
\hline Surface & & $(250.7-379.3)$ & $(4.3-10.8)$ & $(1.2-2.4)$ \\
\hline Non-burrow (Site A) & 4 & 19.6 & 7.2 & 1.9 \\
\hline Integrated & & $(0.0-78.4)$ & $(6.1-8.1)$ & $(1.1-2.7)$ \\
\hline Non-burrow (Site A) & 5 & 1.1 & 4.2 & 1.3 \\
\hline Surface & & $(0.0-9.9)$ & $(1.8-8.3)$ & $(0.9-2.0)$ \\
\hline Muddy creekbank (Site B) & 4 & 1.7 & 6.3 & 1.9 \\
\hline Integrated & & $(0.0-4.5)$ & $(5.1-27.8)$ & $(1.2-2.7)$ \\
\hline \multicolumn{5}{|l|}{ (B) $\mathrm{ng} \mathrm{g}^{-1}$} \\
\hline Burrows (Site A) & 5 & 104.4 & 8.2 & 1.6 \\
\hline Integrated & & $(53.8-218.9)$ & $(5.6-12.1)$ & $(1.4-1.8)$ \\
\hline Burrows (Site A) & 4 & 219.2 & 4.8 & 1.3 \\
\hline Surface & & $(179.2-270.9)$ & $(3.1-7.7)$ & $(0.8-1.7)$ \\
\hline Non-burrow (Site A) & 4 & 13.1 & 4.8 & 1.3 \\
\hline Integrated & & $(0.0-52.2)$ & $(4.1-5.4)$ & $(0.7-1.8)$ \\
\hline Non-burrow (Site A) & 5 & 0.7 & 2.8 & 0.9 \\
\hline Surface & & $(0.0-7.1)$ & $(8.0-11.6)$ & $(0.6-1.3)$ \\
\hline Muddy creekbank (Site B) & 4 & 1.7 & 6.3 & 1.6 \\
\hline Integrated & & $(0.0-4.5)$ & $(5.1-27.8)$ & $(0.9-1.9)$ \\
\hline
\end{tabular}


Sigma (St. Louis, MO, USA). The identities of the extracted compounds have been established by gas chromatography/mass spectronomy in separate experiments (Lincoln, Fielman, Lovell, \& Woodin unpubl.).

\section{RESULTS}

Five sample locations distributed throughout the North Inlet estuary are shown in Fig. 1. The Notomastus lobatus bed extends from the intertidal to the subtidal at Site A, a muddy sandflat. The bed is extensive, measuring ca $100 \mathrm{~m}$ by $300 \mathrm{~m}$ and has been in existence for at least 12 yr (Stancyk pers. comm.). Other infauna commonly encountered at this location include the brittlestars Microphiopholis gracillima and Microphiopholis atra and a subsurface feeding maldanid polychaete, Clymenella torquata. No animals producing burrows similar to that of $N$. lobatus or of physically similar appearance to this species are found in the N. lobatus bed. No other halometabolite-producing worm species were found at this site and no halometabolite-producing species were observed at any of the other sites used in this study. While it is very difficult to select study sites identical in all significant environmental parameters other than occupancy by $N$ lobatus, the worm bed and adjacent sandflat areas lacking $N$. lobatus were extremely similar in elevation, degree of tidal inundation, and sediment grain size, and were in very close proximity to each other. The contaminated and non-contaminated sites (Fig. 1, Site A) were our principal study sites.

Compound values at the study sites are given in Table 1. Although 4-bromophenol was detectable outside the Notomastus lobatus worm bed, concentrations within the bed were significantly different for surface sediments and integrated sediment cores (KolmogrovSmirnov Two Sample Test, $D n=1, \mathrm{p}<0.05, D n=1$, $p<0.05$ ). Some degree of bromophenol contamination was observed at all locations examined but significant 4 -bromophenol contamination occurred only within the $N$. lobatus bed adjacent to $N$. lobatus burrows. Levels of 4-bromophenol contamination in these sediments vary due to the solubility of this compound in seawater. The other compounds are more lipophilic and tend to concentrate on the surfaces of sediment particles (Hansch \& Leo 1979). Another factor which can affect localized levels of compounds in the sediment is the ability of $N$. lobatus to move the top portion of its burrow, occupied by its tail, a short distance (D. E. Lincoln \& S. A. Woodin pers. comm.). Burrow opening relocation through this mechanism could occur within the region sampled with our coring technique. Both 2,4-dibromophenol and 2,4,6-tribromophenol may be transported within the system by sediment transloca-
Table 2. Cell numbers and net assimilation of ${ }^{3} \mathrm{H}$-acetate in sediment cores taken adjacent to Notomastus lobatus burrows, non-burrow control locations, a muddy creekbank, and a sandy creekbank. Homogeneous groups based on the Tukey-Kramer test. Data are presented as mean \pm 1 standard error $\left(\mathrm{n}=4,{ }^{3} \mathrm{H}\right.$-acetate net assimilation; $\mathrm{n}=6$, for cell numbers)

\begin{tabular}{|c|c|c|}
\hline \multicolumn{2}{|c|}{$\begin{array}{cc}\text { Location } & { }^{3} \mathrm{H} \text {-acetate net assimilation } \\
\left(\mathrm{pmol} \mathrm{ml} \mathrm{l}^{-1} \mathrm{~h}^{-1}\right)\end{array}$} & \multirow{2}{*}{$\begin{array}{c}\text { Cell numbers } \\
\left(10^{9} \text { cells } \mathrm{ml}^{-1}\right) \\
1.2 \pm 0.048^{\circ}\end{array}$} \\
\hline $\begin{array}{l}\text { Burrows (Site A) } \\
\text { Non-burrow }\end{array}$ & $12.7 \pm 5.0^{\circ}$ & \\
\hline locations (Site A) & $11.9 \pm 1.4^{\circ}$ & $1.2 \pm 0.071^{\circ}$ \\
\hline $\begin{array}{l}\text { Muddy } \\
\text { creekbank (Site B) } \\
\text { Sandy }\end{array}$ & $11.1 \pm 1.6^{\circ}$ & $1.7 \pm 0.025$ \\
\hline $\begin{array}{l}\text { creekbank (Site C } \\
\text { ANOVA }^{b}\end{array}$ & $F=2.42, \mathrm{p}>0.10$ & $\begin{aligned} & 1.0+0.057^{\circ} \\
F= & 21.55, \mathrm{p}<0.0001\end{aligned}$ \\
\hline $\begin{array}{l}{ }^{\mathrm{d}} \text { Not determined } \\
{ }^{\mathrm{b}} \text { Analysis of varia } \\
\text { acetate net assim }\end{array}$ & $\begin{array}{l}\text { ce between all so } \\
\text { ation and cell num }\end{array}$ & $\begin{array}{l}\text { sample sites for }{ }^{3} \mathrm{H} \text { - } \\
\text { mbers }\end{array}$ \\
\hline
\end{tabular}

tion, and dibromophenol may be produced by worm species other than $N$. lobatus in this estuary (King 1986, Woodin et al. 1987).

Bacterial numbers were determined by acridine orange direct microscopic count at a total of 4 sampling locations, including near-burrow locations within the worm bed, non-burrow control locations, a sandy creekbank outside of the bed and a muddy creekbank site. Cell numbers determined at all locations were from integrated core samples extending from the surface to a depth of $6 \mathrm{~cm}$ and included both surface (oxic) and deeper (anoxic) sediments. Greater than $85 \%$ of cells were either attached to particles or biofilm material before treatment for cell counts. Significant differ-

Table 3. Bacterial cell numbers in cores taken $2 \mathrm{~cm}$ and $10 \mathrm{~cm}$ away from Notomastus lobatus burrows. Samples were collected on 17 February 1991 and cell number determined by acridine orange direct counting

\begin{tabular}{|c|c|c|}
\hline \multirow[t]{2}{*}{ Burrow } & \multicolumn{2}{|c|}{ Cell numbers $\left(\times 10^{9}\right.$ cells $\left.\mathrm{ml}^{-1}\right)$} \\
\hline & $\mathrm{cm}$ distance & $10 \mathrm{~cm}$ distance \\
\hline 1 & 1.80 & 0.93 \\
\hline 2 & 1.10 & 0.94 \\
\hline 3 & 1.20 & 0.82 \\
\hline 4 & 0.79 & 0.73 \\
\hline 5 & 1.20 & 0.84 \\
\hline 6 & 0.93 & 1.00 \\
\hline 7 & 1.00 & 1.40 \\
\hline Mean & 1.10 & 0.95 \\
\hline Standard erro & or 0.12 & 0.08 \\
\hline ANOVA $^{c}$ & & \\
\hline \multicolumn{3}{|c|}{$\begin{array}{l}\text { "Analysis of variance between sets of cores taken at } 2 \text { dis- } \\
\text { tances from } N \text {. lobatus burrows }\end{array}$} \\
\hline
\end{tabular}


Table 4. Net assimilation of ${ }^{3} \mathrm{H}$-acetate and respiration of ${ }^{14} \mathrm{C}$-acetate in sediment cores collected $2 \mathrm{~cm}$ and $10 \mathrm{~cm}$ away from Notomastus lobatus burrows on 23 January 1992. Data are presented as mean \pm standard error $(n=4)$

\begin{tabular}{|c|c|c|c|}
\hline Location & $\begin{array}{l}{ }^{3} \mathrm{H} \text {-acetate net assimilation } \\
\left(\text { pmol } \mathrm{ml}^{-1} \mathrm{~h}^{-1}\right)\end{array}$ & $\begin{array}{c}{ }^{14} \mathrm{C} \text {-acetate respiration } \\
\left(\text { pmol ml } \mathrm{m}^{-1} \mathrm{~h}^{-1}\right)\end{array}$ & $\begin{array}{l}\text { Acetate gross assimilation } \\
\left(\mathrm{pmol} \mathrm{ml} \mathrm{m}^{-1} \mathrm{~h}^{-1}\right)\end{array}$ \\
\hline $2 \mathrm{~cm}$ from burrow (Site A) & $73.6 \pm 9.7$ & $73.6 \pm 7.7$ & 147.2 \\
\hline $10 \mathrm{~cm}$ from burrow (Site $\mathrm{A}$ ) & $106.5 \pm 24.2$ & $50.8 \pm 9.4$ & 157.3 \\
\hline ANOVA $^{d}$ & $F=1.2, p>0.30$ & $F=3.7, p>0.10$ & \\
\hline
\end{tabular}

ences in bacterial cell numbers were found between the muddy creekbank and the other 3 sampling sites tested (ANOVA, $F=21.55, \mathrm{p}<0.001$ ), but not between any of the sandy sites, including the worm burrows and non-burrow control locations (Tukey-Kramer test) (Table 2). No significant differences in cell numbers were found among samples taken $2 \mathrm{~cm}$ and $10 \mathrm{~cm}$ away from the Notomastus lobatus burrows (ANOVA, $F=1.7, p>0.21$ ) (Table 3). Bacterial numbers were not significantly affected by proximity to $N$. lobatus burrows.

Core samples similar to those taken for determination of cell numbers were used in acetate assimilation and respiration measurements. These samples were obtained from burrow locations, non-burrow control locations, and from a sandy creekbank outside of the worm bed. The cores were radiolabeled by injecting ${ }^{3} \mathrm{H}$-acetate (for assimilation rate measurements) or ${ }^{14} \mathrm{C}$ acetate (for respiration rate measurements) at discrete depth intervals, avoiding disturbance artifacts which can arise from slurry preparation (Meyer-Reil 1978, 1986, Dobbs et al. 1989). The rates measured are thus derived from integrated samples extending from the surface to a depth of $6 \mathrm{~cm}$ and include both oxic and anoxic sediments. Biologically available acetate concentration, a parameter which is very difficult to measure accurately (Gibson et al. 1989), was not determined. The close proximity and very similar physical and biological characteristics of the contaminated and uncontaminated sandflat sites indicate that little difference in carbon metabolism between these sediments should be expected. Acetate assimilation rates in muddy sediments and in burrow and non-burrow control locations were not significantly different (ANOVA, $F=2.4, p>0.10$ ) (Table 2). There was also no significant difference in rates of acetate net assimilation in cores taken $2 \mathrm{~cm}$ and $10 \mathrm{~cm}$ away from Notomastus lobatus burrows (ANOVA, $F=$ $1.2, p>0.30$ ) (Table 4 ) or in acetate respiration rates in cores taken $2 \mathrm{~cm}$ and $10 \mathrm{~cm}$ from the burrows (ANOVA, $F=3.7, \mathrm{p}>0.10$ ) (Table 4). Bacterial activity, as measured by net and gross assimilation of a key substrate, was unaffected by proximity to N. lobatus burrows.

Benthic microalgal biomass, primary production, and biomass specific production (assimilation number) was measured around the worm burrow openings, in an adjacent sandflat, and in soft, muddy sediments at 4 randomly chosen locations in the estuary (Table 5). The data were grouped according to location (worm bed, sandflat, mud, creekbank sites) to determine the effects of Notomastus lobatus burrows and bromophenol-contaminated sediments on microalgal biomass and production. Microalgal biomass (chl a) was significantly different between the 3 locations (ANOVA, $F=175, \mathrm{p}<0.01$ ), but the worm bed and sandflat areas were not significantly different from one another ( $p>0.05$ ) (Table 5). Primary production was also signif-

Table 5. Comparison of benthic microalgal biomass, primary production, and biomass specific production estimates around Notomastus lobatus burrows in the worm bed, in an adjacent non-burrow location, and from randomly chosen intertidal muddy sediments in North Inlet. Values are means ( \pm 1 standard error) for all cores in the group. F-values and p-values were obtained using ANOVA. Underline indicates homogeneous groups based on the Tukey-Kramer test

\begin{tabular}{|c|c|c|c|c|c|}
\hline & Burrow (Site A) & Non-burrow location (Site A) & Mud (Site D) & $F$ & $\mathrm{p}$ \\
\hline No. of cores (n) & 5 & 5 & 4 & & \\
\hline No. of measurements & 25 & 25 & 20 & & \\
\hline Biomass (mg chl a $\mathrm{m}^{-2}$ ) & $20.1(1.23)$ & $24.3\lfloor 0.97\rfloor$ & $50.8(1.45)$ & 175 & $<0.001$ \\
\hline Production $\left(\mathrm{mmol} \mathrm{O} \mathrm{O}^{-2} \mathrm{~h}^{-1}\right\}$ & $4.17(0.31)$ & $5.84(0.97)$ & $11.6(1.72)$ & 11.2 & $<0.01$ \\
\hline $\begin{array}{l}\text { Biomass specific production } \\
\left(\mu \mathrm{mol} \mathrm{O}_{2} \mathrm{mg} \mathrm{chl} \mathrm{a}^{-1} \mathrm{~h}^{-1}\right)\end{array}$ & $212(21.8)$ & $239(39.1)$ & $217(26.7)$ & 0.23 & 0.80 \\
\hline
\end{tabular}



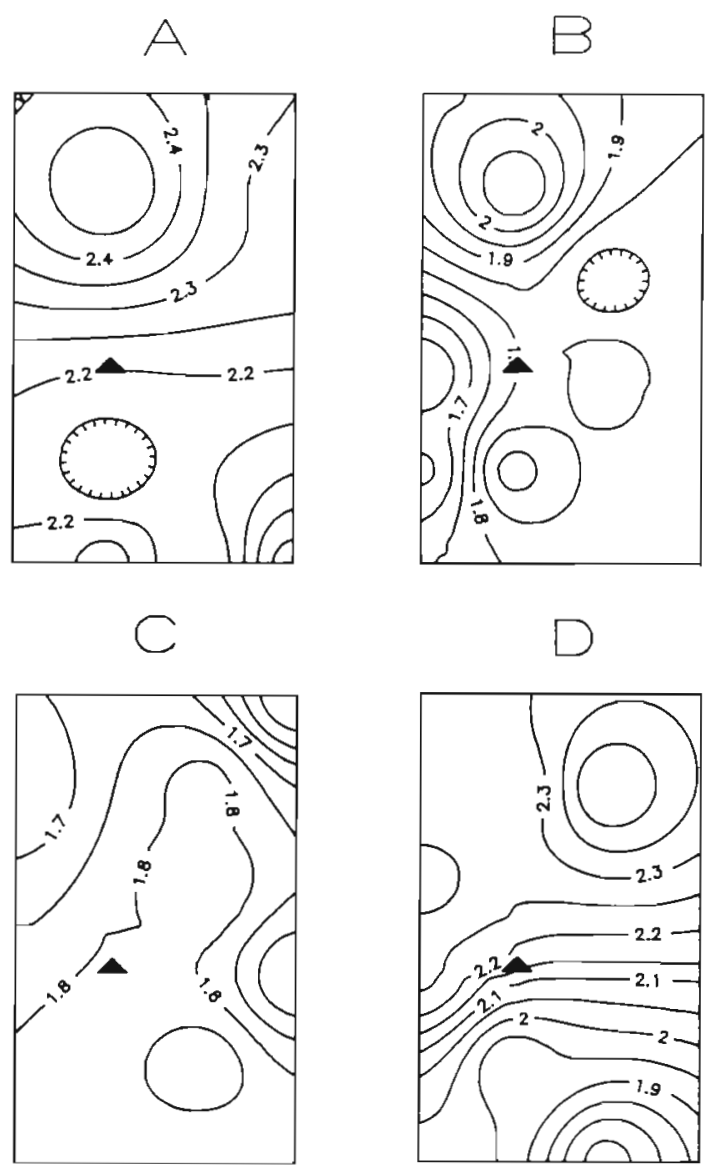

Fig. 3. Isopleths of bacterial numbers $\left(10^{9}\right.$ cells $\left.\mathrm{ml}^{-1}\right)$ around Notomastus lobatus burrows. Symbols used in the plots are standard topographic symbols; closed loops with internal hatchmarks indicate values decreasing from the loop inward. Each plot represents one plate sampled over a burrow. Dimensions of sampling plate and of wells within it are shown in Fig. 2. (ム) Location of worm burrow. Samples were collected on 19 March 1992

icantly different for the 3 locations (ANOVA, $F=11.2$, $p<0.01$ ) (Table 5), but again, the worm bed and sandflat areas were not significantly different $(p>0.05)$. Biomass specific production (i.e. primary production normalized to biomass, or assimilation number) was not significantly different (ANOVA, $F=0.23, p>0.80$ ) (Table 5) between the 3 locations.

Visual inspections of spatial distributions of bacterial numbers (Fig. 3), and microalgal biomass (Fig. 4) indicated no obvious localized effects of the worm burrows. Spatial patchiness is indicated by the isopleths of bacterial numbers and microalgal biomass. Spatial distribution of several meiofauna groups also showed no obvious effects of proximity to the worm burrow. Nematodes, foraminifera, and copepods were the major taxa comprising the meiofauna in the $N$. lobatus

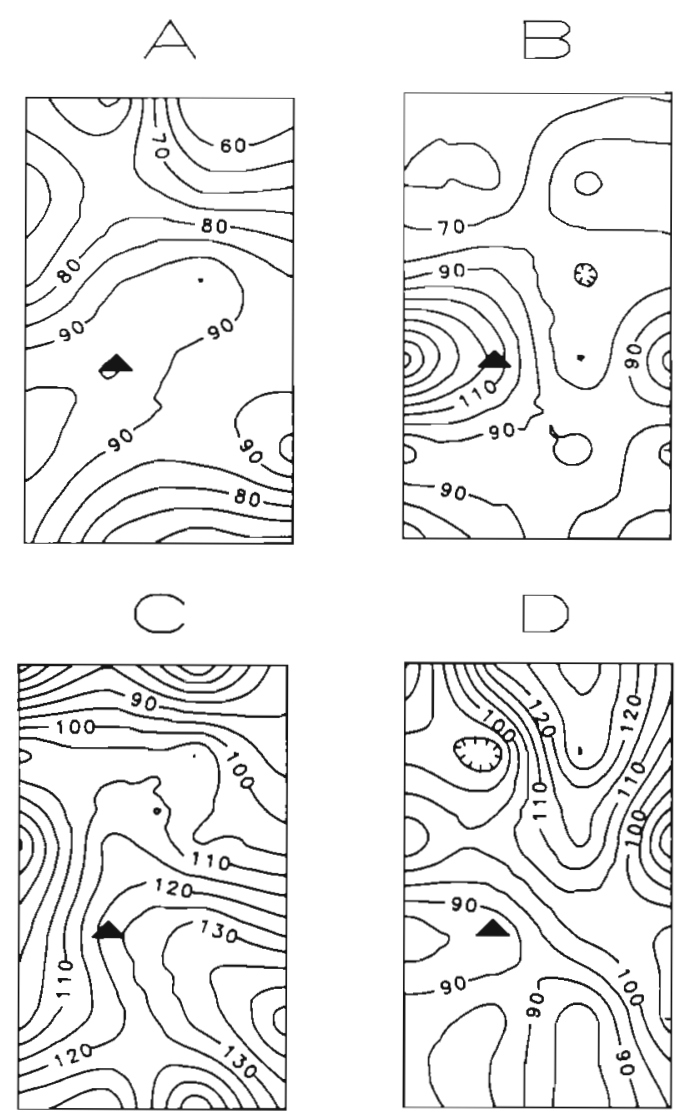

Fig. 4. Isopleths of microalgal biomass ( $\mathrm{mg} \mathrm{chl} \mathrm{a} \mathrm{m}^{-2}$ ) around Notomastus lobatus burrows. Symbols in plots are standard topographic symbols; closed loops with internal hatchmarks indicate values decreasing from the loop inward. Each plot represents one plate sampled over a burrow. Dimensions of sampling plate and of wells within it are shown in Fig. 2. (A) Location of the worm burrow. Samples were collected on 11 June 1991

bed (Table 6). Polychaetes, bivalves, and other organisms were present in some samples but their numbers were too low for meaningful analysis.

\section{DISCUSSION}

Bromophenol production by infaunal polychaetes and hemichordates results in extensive sediment contamination (King 1986, Woodin et al. 1987). The propagation and maintenance of this sediment contamination is particularly interesting in the case of the capitellid polychaete Notomastus lobatus. This organism produces 4-bromophenol, which is soluble in sea water, as well as smaller quantities of 2,4-dibromophenol and 2,4,6-tribromophenol, which are less watersoluble and substantially more lipophilic (Hansch \& Leo 1979). Sediments within the $N$. lobatus bed, but outside of the polychaetes' burrows, are significantly 
Table 6. Meiofaunal numbers for nematodes, foraminifera, and copepods. Data are presented as mean \pm 1 standard deviation. Twelve wells per plate were counted. Samples were collected on 19 March 1992

\begin{tabular}{|lccc|}
\hline Sample & Nematodes (ind. $10 \mathrm{~cm}^{-2}$ ) & Foraminifera (ind. $10 \mathrm{~cm}^{-2}$ ) & Copepods (ind. 10 $\mathrm{cm}^{-2}$ ) \\
\hline Plate 1 & $1500 \pm 955$ & $457 \pm 69$ & $49.2 \pm 73.4$ \\
Plate 2 & $1660 \pm 513$ & $428 \pm 200$ & $21.3 \pm 41.9$ \\
Plate 3 & $2075 \pm 1025$ & $410 \pm 218$ & $21.3 \pm 48.9$ \\
Plate 4 & $1400 \pm 503$ & $442 \pm 166$ & $38.5 \pm 45.5$ \\
Plate 5 & $1171 \pm 575$ & $579 \pm 277$ & $75.1 \pm 99.0$ \\
X plates & $1561 \pm 338$ & $457 \pm 69$ & $41.1 \pm 22.4$ \\
X wells counted & $1528 \pm 795$ & $457 \pm 220$ & $42.0 \pm 66.1$ \\
\hline
\end{tabular}

contaminated with these compounds. Porewater levels of 4 -bromophenol in the $N$. lobatus bed were as high as $210 \mathrm{nmol} \mathrm{l}^{-1}$ (Lincoln, Fielman, Lovell \& Woodin unpubl.). Levels of 4-bromophenol within the worm bed were 7.5 -fold higher than those found outside the bed, clearly indicating production and accumulation of this compound within the bed. Subsequent experiments have shown that the extraction method used in quantifying 4 -bromophenol underestimated the true values by approximately $40 \%$ (Lincoln, Fielman, Lovell \& Woodin unpubl.), but this underestimation was consistent for all samples analyzed. Thus, 4-bromophenol levels within the worm bed were higher than estimated. There are detectable, though low, levels of bromophenols throughout this salt marsh system. This generalized contamination may be due to worm species other than $N$. lobatus, as well as transport of diand tribromophenols within the system on sediment particles.

The impacts of 4-bromophenol contamination by Notomastus lobatus on the microflora of the worm bed sediments were of particular interest. Worm bromometabolites have been thought to serve as antifouling agents on the surfaces of the animals and within their burrows (Ashworth \& Cormier 1967, Sheikh \& Djerassi 1975, King 1986, Goerke \& Weber 1991), restricting bacterial growth, oxygen consumption, degradation of the burrow wall mucus lining, and potentially preventing wound infection. King (1988) found fewer bacteria in burrows of a bromometabolite-producing hemichordate (Saccoglossus kowalewskyi) compared to burrows of Nereis succinea, a polychaete that produces no brominated compounds. A similar role has been proposed for the bromometabolites of marine algae, but is contradicted by the abundant growth of epiphytic bacteria on these organisms (Chan \& McManus 1969, Corre \& Prieur 1990).

No impact of 4 -bromophenol contamination on worm bed microflora was observed. Notomastus lobatus bed sediment samples were compared to samples taken from a nearby location having similar sediments and elevation in the marsh, but no $N$. lobatus; samples from a separate sandy creekbank; and samples from a muddy creekbank. The only significant differences in bacterial numbers were between the muddy creekbank and the sandy sites. Similarly, no differences were found between bacterial numbers at $2 \mathrm{~cm}$ distance and $10 \mathrm{~cm}$ distance from the $N$. lobatus burrows, and no apparent effect of burrow proximity on bacterial distribution was observed. Bacterial activity, using acetate net and gross assimilation as indicators, was similarly unaffected by proximity to burrows. All of the sandy sites examined were effectively homogeneous with respect to acetate net and gross assimilation. No significant differences between net and gross assimilation of acetate in cores taken at $2 \mathrm{~cm}$ and $10 \mathrm{~cm}$ distances from the burrows were observed. The cores used in these experiments provided integrated samples to $6 \mathrm{~cm}$ depth, including both oxic surface sediments and anoxic subsurface sediments. In the case of cores taken in the $N$. lobatus bed, both surface and subsurface sediments were significantly contaminated with 4-bromophenol.

Benthic microalgae were likewise unaffected by 4 -bromophenol contamination at the levels encountered in the Notomastus lobatus bed. Biomass and productivity within and outside of the $N$. lobatus bed were similar, but differed from those measured in muddier locations. Benthic microalgal communities usually exhibit higher biomass and production in muddy sediments and values reported in this study are comparable to measurements made at several other locations in this estuary (Pinckney \& Zingmark 1993). There was also no significant effect of proximity to the burrows on the distribution of microalgal biomass. None of these experiments showed significant effects of bromophenols on bacterial numbers and activity, microalgal biomass and productivity, and meiofaunal distributions. However, these experiments were designed to detect gross changes in population sizes and activities, not shifts in species composition. Biogenic bromophenol effects on bacterial and microalgal community struc- 
ture and composition in the $N$. lobatus bed may be significant, but will require further study.

Copepods, nematodes, and foraminifera were sufficiently numerous in our samples to be reproducibly counted and were all distributed patchily, as expected from previous studies (Findlay 1981, Coull 1985, Pinckney \& Sandulli 1990). Jensen et al. (1992) found lower numbers of meiofauna in burrows of a bromometabolite-producing enteropneust than in burrows of nearby worms which did not produce bromometabolites. We found no obvious effect of biogenic 4 bromophenol on these meiofaunal groups. Values for meiofauna in the $N$. lobatus bed fall within the range of values reported by Coull (1985), who surveyed meiofaunal populations at a nearby site over an $11 \mathrm{yr}$ period.

The absence of a detectable antimicrobial impact of 4 -bromophenol contamination within the Notomastus lobatus bed is significant for a number of reasons. $N$. lobatus is a subsurface sediment deposit feeder that would be expected to obtain at least a portion of its organic carbon and nitrogen requirements from microbial sources (Newell 1965, Cammen 1980, Lopez \& Levinton 1987, Dobbs \& Guckert 1988). The biogenic bromophenols in the $N$. lobatus bed had no apparent inhibitory effect on the subsurface sediment microflora. Benthic diatoms contribute a major fraction of primary productivity in the sand flats inhabited by $N$. lobatus (Pinckney \& Zingmark 1991) and produce copious exopolymers which stabilize the sediments (Holland et al. 1974). Both groups of microorganisms are intimately involved in sediment biogeochemical processes. Inhibition of the microflora of the worm bed would clearly have negative impacts on infaunal organisms like N. lobatus, but 4-bromophenol had no detectable antimicrobial impact at the levels found in the worm bed sediments. The microflora appear to be well adapted to constant exposure to biogenic bromophenols at levels which would be considered significant if the compounds were of anthropogenic origin. This adaptation may include selection for species which can catabolize bromophenols (Steward, Dixon \& Lovell unpubl.).

An antimicrobial role for bromophenols in the burrows of Notomastus lobatus is still possible, due to the high levels of these compounds in this location. It is also possible that even if no broad spectrum antimicrobial activity occurs in the burrows, particular parasitic or pathogenic species of bacteria or epifaunal metazoans are inhibited. Our results however strongly suggest that microbial activity is unaffected by these compounds.

Two additional hypotheses concerning the role of worm bromometabolites have been proposed. The tissues of these animals contain high levels of the bromi- nated compounds (Yoon, Chen, Lovell, Lincoln, Knapp \& Woodin unpubl.) leading Woodin et al. (1987) to hypothesize that these compounds have an antipredator function. Infauna are often subject to sublethal (partial) predation, where any body part extending above the sediment surface can be bitten off by predators. The significance of sublethal predation to infaunal worms is shown by the high incidence of regenerating individuals in populations of maldanid, arenicolid, and spionid worms (Mangum 1964, de Vlas 1979b, Zajac 1985), as well as by the presence of the corresponding pieces of infaunal organisms in the guts of predators (Trevallion et al. 1970, de Vlas 1979a, Peterson \& Quammen 1982). Notomastus lobatus does not exhibit common anti-predation defensive strategies, such as rapid burrowing or withdrawal into its burrow, and it inhabits sediments which are easily excavated by predatory species (Grant 1983). Bromometabolites, which impart an unpleasant smell and (presumably) taste to the animal tissues, might reduce this predation pressure (Woodin \& Marinelli 1991). A similar repellent function has also been proposed for bromometabolites in macroalgae (Steinberg 1985, Hay et al. 1987, Hay \& Fenical 1988, Lubchenco \& Carlson 1988, Hay et al. 1990). The antipredator hypothesis is certainly attractive in the case of $N$. lobatus, but has not been directly demonstrated.

The Notomastus lobatus bromophenols may also serve as negative cues for recruitment of the planktonic larvae of other infaunal species (Woodin 1991). This function has been well established for the bromobenzylalcohol produced by Thelepus crispus (Woodin \& Marinelli 1991, Woodin 1993). Bromobenzylalcohol is highly repellent to larvae of the polychaete Nereis vexillosa, which rejects sediments contaminated with this compound by $T$. crispus (Woodin \& Marinelli 1991). N. lobatus bromophenols may serve a similar function, restricting infaunal species diversity in the sediments it occupies.

Large-scale sediment contamination by bromometabolite-producing infaunal marine worms creates a stable selection pressure for microflora adapted to exposure to these toxic compounds. These selected microorganisms should include bacteria capable of deriving carbon and/or energy from degradation of the bromometabolites (Neilson 1990). Such organisms are potentially very useful in bioremediation processes, but the diversity and degradation capabilities of existing pure cultures are somewhat limited (Neilson 1990). Bromometabolite-contaminated worm beds should provide an excellent source of bacterial strains capable of degrading haloorganic compounds. Future studies will examine bacterial community structure, bromophenol-degrading bacteria, and rates of bromophenol degradation in these contaminated sediments. 
Acknowledgements. We acknowledge Sarah Woodin for identification of worms, and Sarah Woodin, David Lincoln. and 3 anonymous reviewers for their helpful comments on the manuscript. We also thank Geralyne Lopez-de Victoria for aid in statistical analysis and Clint Cook for preparation of Fig. 2. This work was supported by National Science Foundation Grant BSR-8906705 to C.R.L., and grants in aid to C.C.S. and J.P. from the Slocum-Lunz Foundation

\section{LITERATURE CITED}

Ashworth, R. B., Cormier, M. J. (1967). Isolation of 2,6-dibromophenol from the marine hemichordate, Balanoglossus biminiensis. Science 155: 1558-1559

Beukema, J. J. (1982). Annual variation in reproductive success and biomass of the major macrozoobenthic species living in a tidal flat area of the Wadden Sea. Neth. J. Sea Res. 16: $37-45$

Beukema, J. J., de Vlas, J. (1979). Population parameters of the lugworm, Arenicold marind, living on tidal flats in the Dutch Wadden Sea. Neth. J. Sea Res. 13: 331-353

Cammen, L. M. (1980). The significance of microbial carbon in the nutrition of the deposit feeding polychaete Nereis succinea. Mar. Biol. 61:9-20

Chan, E. C. S. MicManus, E. A. (1969). Distribution, characterization, and nutrition of marine microorganisms from the algae Polysiphonia lanosa and Ascophyllum nodusum. Can. J. Microbiol. 15: 409-420

Chen, Y P., Lincoln, D. E., Woodin, S. A., Lovell, C. R. (1991). Purification and properties of a unique flavin-containing chloroperoxidase from the capitellid polychaete Notomastus lobatus. J. biol. Chem. 266: 23909-23915

Corre, S., Prieur, D. (1990). Density and morphology of epiphytic bacteria on the kelp Laminaria digitata. Bot. Mar. 33: $515-523$

Coull, B. C. (1985). Long-term variability of estuarine meiobenthos: an 11 year study. Mar. Ecol. Prog. Ser 24: $205-218$

Dame, R., Chrzanowski, T., Bildstein, K., Kjerve, B., McKellar, H., Nelson, D., Spurrier, J., Stancyk, S., Stevenson, H., Vernberg, J., Zingmark, R. (1986). The outwelling hypothesis and North Inlet, South Carolina. Mar. Ecol. Prog. Ser. 33: 217-229

de Vlas, J. (1979a). Annual food intake by plaice and flounder in a tidal flat area in the Dutch Wadden Sea, with special reference to consumption of regenerating parts of macrobenthic prey. Neth. J. Sea Res. 13: 117-153

de Vlas, J. (1979b). Secondary production by tail regeneration in a tidal flat population of lugworms (Arenicola marina), cropped by flatfish. Neth. J. Sea Res. 13: 362-393

Dobbs, F. C., Guckert, J. B. (1988). Microbial food resources of the macrofaunal-deposit feeder Ptychodera bahamensis (Hemichordata: Enteropneusta). Mar. Ecol. Prog. Ser. 45: $127-136$

Dobbs, F. C., Guckert, J. B., Carman, K. R. (1989). Comparison of three techniques for administering radiolabeled substrates to sediments for trophic studies: incorporation by microbes. Microb. Ecol. 17: 237-250

Faulkner, D. J. (1984). Marine natural products: metabolites of marine algae and herbivorous molluscs. Nat. Prod. Rep. 1: $251-280$

Fenical, W. (1975). Halogenation in the Rhodophyta - a review. J. Phycol. 11: 245-259
Findlay, S. E. G. (1981). Small scale spatial distribution of mejofauna on a mud- and sandflat. Estuar. coast. mar. Sci. 12: $472-484$

Gibson, G. R., Parkes, R. J., Herbert, R. A. (1989). Biological availability and turnover rate of acetate in marine and estuarine sediments in relation to dissimilatory sulphate reduction. FEMS Lett. 62: 303-306

Goerke, H., Weber, K. (1991). Bromophenols in Lanice conchilega (Polychaeta, Terebellidae): the influence of sex, weight and season. Bull. mar. Sci. 48: 517-523

Grant, J. (1983). The relative magnitude of biological and physical sediment reworking in an intertidal community. J. mar. Res. 41:673-689

Hansch, C., Leo, A. (1979). Substituent constants for correlation analysis in chemistry and biology. Wiley, New York

Hay, M. E., Fenical, W. (1988). Marine plant-herbivore interactions: the ecology of chemical defense. A. Rev. Ecol. Syst. 19: 111-145

Hay, M. E., Duffy, J. E., Paul, V. J., Renaud, P. E., Fenical, W. (1990). Specialist herbivores reduce their susceptibility to predation by feeding on the chemically defended seaweed Avrainvillea longicaulis. Limnol. Oceanogr. 35: $173 \dot{4}-1743$

Hay, M. E., Pfister, C. A., Fenical, W. (1987). Chemical defenses against different marine herbivores: are amphipods insect equivalents? Ecology 68: 1567-1580.

Hewson, W. D., Hager, L. P. (1980). Bromoperoxidases and halogenated lipids in marine algae. J. Phycol. 16:340-345

Higa, T., Scheuer, P. J. (1975a). 3-Chloroindole, principal odorous constituent of the hemichordate Ptychodera flava laysanica. Naturwissenschaften 62: 395-396

Higa. T., Scheuer, P. J. (1975b). Constituents of the marine annelid Thelepus setosus. Tetrahedron 31: 2379-2381

Hobbie, J. E., Daley, R. J., Jasper, S. (1977). Use of Nuclepore filters for counting bacteria by fluorescence microscopy Appl. environ. Microbiol. 33: 1225-1228

Holland, A. F., Zingmark, R. G., Dean, J. M. (1974). Quantitative evidence concerning the stabilization of sediments by marine benthic diatoms. Mar. Biol. 27: 191-196

Jannun, R., Nuwayhid, N., Coe, E. (1981). Biological bromination: bromoperoxidase activity in the murex sea-snail Fed. Proc. 40: 1774

Jensen, P., Emrich, R., Weber, K. (1992). Brominated metabolites and reduced numbers of meiofauna organisms in the burrow wall lining of the deep-sea enteropneust Sterobalanus canadensis. Deep Sea Res. 39: 1247-1253

King, G. M. (1986). Inhibition of microbial activity in marine sediments by a bromophenol from a hemichordate. Nature 323: $257-259$

King, G. M. (1988). Dehalogenation in marine sediments containing natural sources of halophenols. Appl. environ. Microbiol. 54: 3079-3085

Lopez, G. R., Levinton, J. S. (1987). Ecology of deposit-feeding animals in marine sediments. Q. Rev. Biol. 62: 235-259

Lorenzen, C. (1967). Determination of chlorophyll and pheopigments: spectrophotometric equations. Limnol Oceanogr 12: 343-346

Lubchenco, J., Carlson, D. J (1988). Distribution and antiherbivore function of brominated phenols in a temperate red alga. Bull. Ecol. Soc. Am. A.bstracts 69: 212-213

Mangum, C. P. (1964). Studies on speciation in maldanid polychaetes of the North American Atlantic coast. II Distribution and competitive interaction of five sympatric species. Limnol. Oceanogr. 9: 12-26

Meyer-Reil, L.-A. (1978). Uptake of glucose by bacteria in the sediment. Mar. Biol. 44: 293-298 
Meyer-Reil, L.-A. (1986). Measurement of hydrolytic activity and incorporation of dissolved organic substrates by microorganisms in marine sediments. Mar. Ecol. Prog. Ser 31. 143-149

Neilson, A H. (1990). The biodegradation of halogenated organic compounds. J. appl. Bacteriol. 69: 445-470

Newell, R. C. (1965). The role of detritus in the nutrition of two marine deposit feeders, the prosobranch Hydrobia ulvae and the bivalve Macoma balthica. Proc. Zool. Soc. Lond. 144: $25-45$

Pedersen, M., Saenger, P., Fries, L. (1974). Simple brominated phenols in red algae. Phytochem. 13: 2273-2279

Peterson, C. H., Quammen, M. L. (1982). Siphon nipping: its importance to small fishes and its impact on growth of the bivalve Protothaca staminea (Conrad). J. exp. mar. Biol. Ecol. 63: 249-268

Pinckney, J., Sandulli, R. (1990). Spatial autocorrelation analysis of meiofaunal and microalgal populations on an intertidal sandflat: scale linkage between consumers and resources. Estuar. coast. Shelf Sci. 30: 341-353

Pinckney, J., Zingmark, R. (1991). Effects of tidal stage and sun angles on intertidal benthic microalgal productivity. Mar. Ecol. Prog. Ser. 76: 81-89.

Pinckney, J., Zingmark, R. (1993). Biomass and production of benthic microalgal communities in five typical estuarine habitats. Estuaries (in press)

Powell, E. N. (1977). The relationship of the trace fossil Gyrolithe (= Xenohelix) to the family Capitellidae (Polychaeta). J. Paleontol. 51: 552-556.

Revsbech, N. P., Jorgensen, B. B. (1986). Microelectrodes: their use in microbial ecology. Adv. microb. Ecol. 9: $272-352$

Schmitz, F. J., Gopichand, Y (1978). (7E, $13 \xi$, 15Z)-14,16dibromo-7,13,15-hexadecatrien-5-ynoic acid. A novel dibromo acetylenic acid from the marine sponge Xestospongia muta. Tetrah. Lett. 39: 3637-3640

Sheikh, Y M., Djerassi, C. (1975) 2,6-dibromophenol and 2,4,6-tribromophenols - antiseptic secondary metabolites of Phoronopsis viridis. Experientia 31. 265-392
Steinberg, P. D. (1985). Feeding preferences of Tegula funebralis and chemical defenses of marine brown algae. Ecol. Monogr. 55: 333-349

Steward, C. C., Lovell, C. R. (1992). Improved method for recovery and quantitation of incorporated radiolabel from marine sediment bacteria. J. Microbiol. Meth. 16: 221-230

Steward, C. C., Pinckney, J., Lovell, C. R. (1992). Bacterial numbers and activity, and microalgal bromass and productivity in sediments contaminated with bromophenols produced by the marine polychaete Notomastus lobatus. Abstract N-75. In: Abstr A. Meet. Am. Soc. Microbiol. 1992. American Society for Microbiology, Washington, DC, p. 304

Trevallion, A., Edwards, R. R., Steele, J. A. (1970). Dynamics of a benthic bivalve. In: Steele, J. A. (ed.) Marine food chains. Univ. California, Berkeley, p. 285-295

White, R. H., Hager, L. P. (1977). Occurrence of fatty acid chlorohydrins in jellyfish lipids. Biochemistry 16: 4944-4948

Woodin, S. A. (1991). Recruitment of infauna: positive or negative cues? Am. Zool. 31: 797-807

Woodin, S. A., Marinelli, R. (1991). Biogenic habitat modification in marine sediments: the importance of species composition and activity. Symp. Zool. Soc. Lond. 63: $231-250$

Woodin, S. A., Walla, M. C., Lincoln, D. E. (1987). Occurrence of brominated compounds in soft-bottom benthic organisms. J. exp. mar. Biol. Ecol. 107: 209-217

Woodin, S. A., Marinelli, R. Lincoln, D. E. (1993). Allochemical inhibition of recruitment in a sedimentary assemblage. J. Chem. Ecol. (in press)

Yoon, W. B., Rosson, R. A. (1990). Improved method of enumeration of attached bacteria for study of fluctuation in the abundance of attached and free-living bacteria in response to diel variation in seawater turbidity. Appl. environ. Microbiol. 56: 595-600

Zajac, R. N. (1985). The effects of sublethal predation on reproduction in the spionid polychaete Polydora ligni Webster. J. exp. mar. Biol. Ecol. 88:1-19

Manuscript first received: August 5, 1992

Revised version accepted: November 19,1992 